\title{
Student Use of Online Catalogs and Other Information Channels
}

\author{
Ingrid Hsieh-Yee
}

\begin{abstract}
Many information channels are available to students, but it is not clear how students select and use them. A survey of juniors at two universities found online catalogs to be the most commonly used information channel. Students identified "convenience" and "quality of data" as the top two factors in their choice of information channel. Not many students accessed the online catalog remotely. Most conducted keyword and subject searches, but few seemed to understand the differences between them. Students searched the online catalog file and the databases containing the most recent literature more frequently than other databases, and had positive views about searching the system. Analyses of selected characteristics of students showed that race, school, and economic background contributed to their information-seeking behavior. The study affirms the value of librarians and of formal information channels, suggests ways to augment the online catalog, and reminds librarians that equal access to information technology does not necessarily lead to equal use.
\end{abstract}

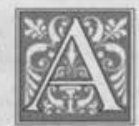

cademic and research libraries have assimilated information technology into their services to support study and teaching. Besides print tools, students now have online catalogs, electronic databases, CDROM databases, and network technology to help them search for information. But it is unclear how students who are under time constraints and academic pressure make use of the information channels available to them. Do they prefer one over the others? What do they take into account in selecting a channel? How do they use the online catalog, which has the most investment from the libraries? And what factors contribute to their use of information channels? Answers to these questions will enable librarians to plan for cost-effective services and will suggest new features to make the online catalog more user-friendly. This study attempts to address these questions.

\section{Literature Review Information-Seeking Behavior of College Students}

Researchers have analyzed the information-seeking behavior of undergraduate students from various perspectives, have examined the problems of library use, and have categorized library anxiety, while exploring the mental states of students in using library resources. ${ }^{1-3}$ Students' use of one or more information sources is often the focus of investigation, as is their use

Ingrid Hsieh-Yee is an Assistant Professor in the School of Library and Information Science at The Catholic University of America; e-mail: hsiehyee@cua.edu. 
of library collections, which has received more attention from researchers than other topics. Several studies confirm that college students make little use of library collections. ${ }^{4}$

Researchers also have investigated possible causes of students' choice of information channels, but the results are less conclusive. Kathleen Dunn reported that undergraduates made considerable use of informal, interpersonal sources such as family members and friends, but ranked teachers first and the library second in terms of their importance in providing information. She also found that students interested in intellectual stimulation and professional success tended to use libraries and experts for needed information. ${ }^{5}$ Tony Mays reported a lack of a clear correlation between academic achievement and use of library collections in Australia, and concluded that undergraduates tend to regard libraries as study halls and consider them superfluous to their educational program. ${ }^{6}$ Nigel Ford, however, found that some students regarded libraries as an extension of what they learn from lectures. ${ }^{7}$ Mays also reported that no prediction can be made between discipline and library use. ${ }^{8} \mathrm{How}$ ever, Stephen A. Osiobe found that discipline related to Nigerian undergraduates' use of information channels, though the relationship was very weak. ${ }^{9}$ As for students' use of information sources, Osiobe found browsing to be most popular, with faculty and the card catalog tying for second, followed by librarians, references in articles and books, abstracts and indexes, and colleagues. Focusing on students' progress through the research process, Barbara Fister reported that they used online catalogs, indexes, and reference tools to browse the field and considered citation network the most direct and efficient way to find relevant information. ${ }^{10}$

\section{College Students and Online Catalogs}

Because academic libraries were among the first libraries to make online catalogs available, much of the literature on online catalogs examines undergraduates' use of online catalogs. College students are reportedly enthusiastic about online catalogs and prefer them to card catalogs. ${ }^{11,12}$ They conduct more subject searches on online catalogs but experience difficulties with these searches. ${ }^{13}$ Nor do they have a clear understanding of the contents of an online catalog. ${ }^{14}$ The availability of keyword access has made it the preferred searching method. For instance, Pat Ensor found that most users (73\%) at Indiana State University use keyword searching. ${ }^{15}$ She also reported that many users $(50 \%)$, like those interviewed by Karen Markey, misunderstand the nature of subject searches and do not know that they need to use the Library of Congress Subject Headings (LCSH) for subject searching. ${ }^{16,17}$

\section{Catalog Improvement and Expansion}

Researchers have explored various methods to enhance or improve subject searches. Markey and Anh N. Demeyer, for instance, studied the use of the Dewey Decimal classification scheme for retrieval. ${ }^{18}$ Jeffrey C. Heustis analyzed LC classification numbers for browsing and Marcia J. Bates suggested incorporating a "superthesaurus" into online catalogs. ${ }^{19,20}$ Mary Micco developed a prototype catalog based on subject clusters while Diane Vizine-Goetz and Karen Markey Drabenstott examined whether matching subject terms with LCSH was the best way to retrieve items relevant to the user's topic. ${ }^{21,22}$ Ray R. Larson experimented with classification clustering in CHESHIRE. ${ }^{23}$ In the meantime, several online catalogs expanded to provide users with access to collections of other libraries and commercially produced databases. However, it is unclear whether the use of such augmented catalogs is the same as that of the earlier online catalogs.

\section{Research Questions}

The present study investigated the infor- 
mation-seeking behavior of students at the American University (AU) and the University of the District of Columbia (UDC) because their student bodies offer an opportunity to examine the relationships between information-seeking behavior and factors such as race and economic background. Specifically, the research questions were:

- What are the information channels used by college students when they work on course-related projects? What factors do students consider in selecting information channels?

- How do college students use ALADIN, an augmented catalog that provides access to the holdings of the Washington Research Library Consortium and several commercial databases?

- How are selected characteristics of students related to their use of information channels, ALADIN and libraries?

\section{Methodology \\ Population and Sample}

The study's population included juniors at AU and UDC because these students could be assumed to have had some experience in looking for information after completing two years of college education. By estimating that 75 percent of the subjects will display different information-seeking behaviors and setting the confidence level in the findings at 95 percent, the author, using a statistical program (StatPac Gold), found the desirable sample size to be 256 . A random sample of 11 percent of the population was then taken, resulting in a sample of 258 juniors.

\section{Survey Instrument}

Because information on college students' information channels is sketchy, the librarians who assisted with the project held two focus group interviews to identify all the channels students explored when they worked on an assignment. Students described how they selected an information channel, used ALADIN and libraries, and offered suggestions for improving library services. The author developed a questionnaire from these findings, pretested it on twenty-four students in the study population, solicited comments from the librarians, and revised it for the main study. (The survey instrument is available from the author upon request.)

\section{Data Collection}

The original plan involved collecting data through a mail survey. The author guaranteed subjects anonymity and provided a self-addressed, stamped return envelope for their responses. Because of a delay in reviewing the study at one university, the first main test did not take place until mid-April of 1994. By then, final examinations were approaching and students did not respond well to the survey. The author then obtained an extension of the deadline from the funding agency so that the research team could collect better data. During the summer, the author revised the survey instrument again and the team decided to collect survey responses on campus in addition to the mail survey. The librarians agreed to post signs around their libraries to encourage participation or to seek faculty assistance in collecting data.

Researchers mailed 258 surveys in September of 1994 and mailed another set of surveys in October to increase the re-

\begin{tabular}{|c|c|c|c|}
\hline \multicolumn{4}{|c|}{$\begin{array}{c}\text { TABLE } 1 \\
\text { Survey Response Rates }\end{array}$} \\
\hline & UDC & $\mathrm{AU}$ & $\begin{array}{l}\text { Row } \\
\text { Total } \\
\end{array}$ \\
\hline Sent & 137 & 121 & 258 \\
\hline Received & 83 & 74 & 157 \\
\hline Response rate & $61 \%$ & $61 \%$ & $61 \%$ \\
\hline Undelivered mail & 34 & 9 & 43 \\
\hline Usable responses & 49 & 65 & 114 \\
\hline Response rate & $48 \%$ & $58 \%$ & $53 \%$ \\
\hline
\end{tabular}




\begin{tabular}{|lc|}
\hline \multicolumn{2}{|c|}{ TABLE 2 } \\
\hline \multicolumn{2}{|c}{ Use of Information Channels } \\
\hline Channel & $\begin{array}{c}\text { Percentage of } \\
\text { Responses }\end{array}$ \\
\hline Online catalogs & 88 \\
Roommates/classmates/friends & 71 \\
References (books or articles) & 70 \\
Librarians & 70 \\
Printed indexes & 63 \\
Stack browsing & 61 \\
Reserved readings & 61 \\
Teachers & 57 \\
Agencies & 50 \\
Students who took the course & 46 \\
Special bibliography & 46 \\
Parents & 42 \\
CD-ROM databases & 28 \\
Online databases & 19 \\
\hline
\end{tabular}

"Respondents reported all the information channels they have used, so the total for each channel is potentially $100 \%$.

sponse rate. By mid-November, researchers received a total of 157 responses, resulting in a response rate of 61 percent. After excluding incomplete and undelivered surveys, the response rate went down to 53 percent, with a total of 114 usable survey (see table 1).

Data collection on campus met with varying success. AU contributed forty-

\begin{tabular}{|c|c|}
\hline $\begin{array}{c}\text { TABLE } 3 \\
\text { Frequently Used } \\
\text { Information Channels }\end{array}$ & \\
\hline & Percentage \\
\hline $\begin{array}{l}\text { Most frequently used } \\
\text { channels }\end{array}$ & \\
\hline Online catalogs & 53 \\
\hline Print indexes & 11 \\
\hline Teachers & 11 \\
\hline $\begin{array}{l}\text { Second most frequently used } \\
\text { channels }\end{array}$ & \\
\hline Online catalogs & 16 \\
\hline References (books or articles) & s) 14 \\
\hline Print indexes & 12 \\
\hline
\end{tabular}

four completed surveys, and UDC twentyfive surveys. To determine whether campus respondents and mail respondents displayed different behaviors, the author performed Chi-square tests on forty-four selected dependent variables. Test results show that the two groups differed in only two variables, so the researchers concluded that no separate analyses were necessary. The final analysis included seventy-four surveys from UDC and 109 surveys from $A U$.

\section{Data Analysis}

A research assistant coded data and entered them into StatPac Gold, and the author compiled descriptive statistics and performed Chi-square tests to analyze the associations between variables.

\section{Findings}

\section{Profiles of Respondents}

Forty percent of the respondents were enrolled in UDC, and the rest in AU. Nearly 60 percent were female, and 39 percent male. Whites represented 51 percent of the respondents, African Americans 29 percent, and Asians and Hispanics ten percent. The other ten percent did not specify their race. As for economic background, slightly more than 52 percent of the respondents came from families with an annual income of more than $\$ 35,000$, and 65 percent of the respondents had a part-time job. Very few of the respondents $(18 \%)$ had children.

\section{Findings on Information Sources}

Information channels. Students identified fourteen information channels during the focus group interviews. Most survey respondents $(88 \%)$ said they used online catalogs, and at least 63 percent reported consulting roommates and friends, book and article references, librarians, and printed indexes. It is somewhat surprising that only 19 percent of the students used online databases and 28 percent used CD-ROMs. Such low use, furthermore, was not because of students' 


\begin{tabular}{|c|c|c|}
\hline $\begin{array}{r}\text { TABLI } \\
\text { Factors Affecting Informa }\end{array}$ & $\begin{array}{l}\text { E } 4 \\
\text { tion } \mathrm{Cl}\end{array}$ & Selection \\
\hline Factor & Score ${ }^{a}$ & Ranking \\
\hline $\begin{array}{l}\text { Convenience } \\
\text { The source is easy } \\
\text { for me to get to }\end{array}$ & 3.43 & 1 \\
\hline $\begin{array}{l}\text { Quality of data } \\
\text { I generally find very good } \\
\text { information this way }\end{array}$ & 4.02 & 2 \\
\hline Ease of use & 4.66 & 3 \\
\hline Availability & 4.80 & 4 \\
\hline $\begin{array}{l}\text { Experience } \\
\text { I used this method many } \\
\text { times in the past }\end{array}$ & 5.70 & 5 \\
\hline Cost & 7.08 & 6 \\
\hline
\end{tabular}

Most learned via "onscreen instructions" $(60 \%)$, and many consulted "library staff" (44\%). Other, less popular methods included "by myself without any help" (38\%), "reading the printed instructions" $(20 \%)$, and "from a friend" $(18 \%)$. Data suggest that the use of ALADIN was a fairly solitary activity. Typically, a student learned to use it by reading instructions on the screen; seeking the help of library staff, if necessary; or exploring the system by him- or herself. Students were less likely to read the

lack of knowledge-more than half of the respondents had knowledge of CD-ROM databases, 43 percent had searched them, and 44 percent knew about online databases. In spite of the rapid growth of online databases and CD-ROM titles, few students used them for needed information. Table 2 presents students' use of information channels.

As table 3 shows, among the 14 channels, students showed a clear preference for online catalogs. More than half of the respondents listed them as the most frequently used method, and 16 percent reported them the second most frequently used method. Students also consulted print indexes, teachers or citation references, but much less frequently than online catalogs.

Factors in channel selection. Of the six factors that may have affected their selection of information channels, students identified "convenience" and "quality of data" as the top two. "Ease of use" ranked third, followed by "availability," "experience," and "cost" (see table 4).

\section{Experience with ALADIN}

Learning ALADIN. Students learned to use ALADIN through various methods. printed instructions or seek help from a friend. The strong reliance on on-screen instructions underscores the importance of system interface, screen displays, and message design. As the system evolves, improvement in these areas will encourage its use.

Remote access. Considering the widespread use of personal computers, it is somewhat surprising that only 28 percent of the respondents accessed ALADIN from outside the library. But this finding is consistent with earlier reports that most undergraduates were in-library users and that faculty, graduate students, and other academic staff tended to be remote users. ${ }^{24,25}$ The reason for the small number of remote student users could be that most students did their research in libraries. Or, it could be that students could not afford a modem or might not know how to use one. As the Internet becomes more popular among students, it will be interesting to monitor whether remote access to ALADIN increases.

Useful bibliographic elements. Students reported three elements that they usually looked for on an ALADIN display. They presented a variety of patterns, with "author-title-subject" being the most 


\begin{tabular}{|c|}
\hline TABLE 5 \\
Sources of Keywords and \\
Subject Headings
\end{tabular}

Source of keywords

What I can think of at the time

Percentage $^{a}$

Earlier readings

78

Records I have retrieved

57

Librarian's help

49

26

Source of subject headings

What I can think of at the time

66

Records I have retrieved

57

Earlier readings

54

Librarian's help

21

LCSH

15

${ }^{2}$ Multiple sources could be reported, so each source is potentially $100 \%$.

common combination (reported by $20 \%$ ), followed by "subject-call number-status of the book" (9\%). Data show that "subject headings" were the most consulted elements, followed by titles, authors, status of the book(s), and call numbers. Students could be using the subject headings to determine the relevance of the records or to expand their search. Currently, ALADIN's default display presents no subject headings. The addition of subject headings to the screen will make the system more helpful to users.

ALADIN search method. Of the five search methods, respondents identified "keyword" as the most frequent method for access. "Subject headings" ranked second, and "author" and "title" tied for the third. A "call number" search was the least used. Consistent with earlier reports that users relied more on keyword searching and tried more subject searches in the online environment, survey respondents searched by keyword and subject heading more often than author, title, or classification number.

Keywords versus subject headings. Findings confirm librarians' concern that users may not understand the differences between a keyword search and a subject heading search. Although 96 percent of the respondents said they understood the differences, only 15 percent said they used LCSH to find subject headings and 66 percent said, "I use whatever I can think of at the time." The reported sources of their keywords and subject headings reveal a similar pattern and suggest that many students probably did not know the differences between keyword searches and subject heading searches (see table 5).

Used properly, subject headings enable a searcher to retrieve relevant items quickly, but it is difficult to come up with a subject heading without consulting an authority list, which for most online cata$\log$ is LCSH. It is therefore surprising that few students sought librarian's assistance in finding subject headings and even fewer consulted LCSH. One possible explanation is that students did not know that they needed to use proper subject headings in subject heading searches. One encouraging sign, however, is that 57 percent of the students turned to the retrieved records for subject heading ideas, although it is unclear whether they examined the subject headings area or the entire records for that purpose. Because students displayed a strong interest in topical searches and many of them conducted subject heading searches with keywords, improvement in this area is critical. As a start, the system could provide on-screen explanations and examples that illustrate the differences between keyword searching and subject heading searching, and librarians could highlight such differences at training workshops. At a more sophisticated level, the system could provide browsing of authorized terms and cross-references, and allow users to find items similar to the records they found. ${ }^{26}$

Advanced search features. Earlier studies reported that advanced features on online catalogs were seldom used. Respondents of this study did use advanced 
features, but the use was low. Fifty-six percent of the students used Boolean operators and 37 percent used limiters, but only 21 percent used truncation. It is encouraging that more than half of the respondents used Boolean operators for their searches, suggesting that students are becoming more sophisticated in searching. Librarians, nonetheless, should continue to educate users of the value of Boolean operators because these operators can increase the relevance of retrieved records, if used properly. Because keyword searches tend to retrieve a large number of records, it is understandable that truncation was not used often to increase retrieval. But the need to narrow retrieval is clear. At the focus group interviews, students said they often preferred items owned by their libraries, but only few students knew how to limit their search by location. Judging from their enthusiasm for this feature, students are likely to appreciate some instruction on limiters.

Files searched. Of the nine files in ALADIN, the online catalog file was the most frequently used, followed by the multisubject periodical index covering literature from 1990 to the present time. The other files such as Newspaper Abstracts, ERIC, Periodical Articles 19831993 , and ABI/Inform were used infrequently. It seems that a catalog to local holdings and an index to recent literature would satisfy most students' needs and that undergraduates had little use for older literature or more specialized subject files.

Views on ALADIN searches. The survey presented descriptions of ALADIN searches with different phrasings to keep respondents from falling into a pattern in responding to them. To make the statis- tics easier to understand, table 6 rephrases these views in presenting students responses.

As table 6 illustrates, students' views on ALADIN searches were generally positive. At least 60 percent of the respondents found title, author, and keyword searches easy, whereas more than 40 percent found subject heading searches easy and reducing a search result easy. Fortyone percent did not know whether call number searches were easy, and those who attempted to search by call number were split on its difficulty. Students were similarly divided on the difficulty of expanding a search when they retrieved too little information the first time.

Another way to analyze the data is to focus on the activities with which users experienced difficulty. Search expansion was difficult for one-third of the respondents; subject heading search, call number search, and search reduction posed problems for nearly one-fifth of them; and very few students knew how to conduct call number searches. Considering the strong interest in conducting subject searches, librarians will be doing a great service to students by providing more instruction on these types of searches. 


\begin{tabular}{|lc|}
\hline \multicolumn{1}{|c|}{ TABLE 7 } \\
Views on Research \\
\hline \hline $\begin{array}{l}\text { Statement } \\
\text { Research is critical } \\
\text { to my future career } \\
\text { Everyone should know } \\
\text { about research } \\
\text { It's nice to know about it, } \\
\text { but I don't have the time } \\
\text { to do that }\end{array}$ \\
$\begin{array}{l}\text { I would like to know more about } \\
\text { it so that I am well prepared } \\
\text { for advanced studies }\end{array}$ \\
$\begin{array}{l}\text { I can always rely on } \\
\text { librarians later }\end{array}$ \\
I want to do the research myself \\
\hline
\end{tabular}

\section{Experience with Libraries}

Student responses to questions on library experience show that they viewed libraries as an important part of their education. They ranked "to work on a paper or an assignment" first and "to meet friends" and "to rest" last as the reasons for using libraries. Sixty percent of the students thought that they knew how to make good use of library resources, whereas 40 percent responded negatively. Librarians can easily address this problem by providing the kinds of assistance students need, such as "information about library collection and services" (57\%), "instruction on how to prepare research papers" (49\%), instructions for using the library $(40 \%)$, and a map of the library $(38 \%)$.

Although 60 percent of the respondents knew how to make good use of li- brary resources, only 46 percent reported success in finding what they needed. The main reasons for the search failure were "holdings failure" (88\%) and "items not on the shelf" $(69 \%)$.

Most students displayed confidence in their understanding of research $(44 \%$ "good understanding," $51 \%$ "some understanding"). As table 7 illustrates, a great majority of them understood the importance of research and more than two-thirds wanted to know more about it.

\section{Roles of Selected Factors}

The author analyzed the relationships between students' characteristics and their information-seeking behavior by performing Chi-square tests on these variables. The independent variables were race, school, economic background, gender, part-time job, and children. The forty-four dependent variables included the five most popular information channels, three major factors in information channel selection, two most popular methods in learning to use ALADIN, frequency of ALADIN use, remote access to ALADIN, understanding of differences between keyword and subject heading searches, sources of keywords for searching, sources of subject headings for searching, use of advanced search features, views on ALADIN searches, ability to make good use of library resources, success in finding needed information in libraries, understanding of research process, views on research, and reasons for using the library.

Chi-square tests associate race with nineteen dependent variables, school with fifteen, and economic background with nine. Some dependent variables were associated with more than one independent variable. Ideally, multiple correlation analyses 


\begin{tabular}{|lccc}
\hline \multicolumn{4}{c|}{$\begin{array}{c}\text { TABLE 9 } \\
\text { Use of ALADIN Associated with Race }\end{array}$} \\
\hline \hline & Chi-square & Cramer's V & Probability \\
\hline $\begin{array}{l}\text { Variable } \\
\begin{array}{l}\text { Learning ALADIN use } \\
\text { from library staff }\end{array}\end{array}$ & 29.734 & 0.425 & 0.000 \\
$\begin{array}{l}\text { Frequency of ALADIN use } \\
\text { Remote access }\end{array}$ & 17.017 & 0.231 & 0.002 \\
$\begin{array}{l}\text { Using whatever I think of } \\
\text { for keywords }\end{array}$ & 14.425 & 0.296 & 0.001 \\
$\begin{array}{l}\text { Using retrieved records } \\
\text { to find keywords }\end{array}$ & 18.528 & 0.336 & 0.000 \\
$\begin{array}{l}\text { Using whatever I think } \\
\text { of for subject headings }\end{array}$ & 7.465 & 0.213 & 0.024 \\
$\begin{array}{l}\text { Use of Boolean operators } \\
\text { Keyword search is easy } \\
\text { Moving between screens } \\
\text { is easy }\end{array}$ & 11.690 & 0.267 & 0.003 \\
$\begin{array}{l}\text { Expanding a search is difficult } \\
\text { Reducing a search is easy }\end{array}$ & 14.855 & 0.309 & 0.001 \\
\hline \begin{tabular}{l} 
p < .05 \\
\hline
\end{tabular} & 19.567 & 0.247 & 0.003 \\
\hline
\end{tabular}

could be used to determine how much each independent variable contributes to the variability of a dependent variable, but because all the data were nominal data, such analyses were not possible. The next section discusses the roles of important factors in detail and summarizes findings on less important factors.

\section{Race As a Factor}

The study analyzed the race factor by Whites, African Americans, and others (Asians and Hispanics combined). Tables 8 through 10 present nineteen dependent variables found to relate to the race factor.

Table 8 shows that four of the five most reported information channels relate to the race factor. Data suggest that African American students were more likely than the other two groups to ask their parents for information and to rely on references in books and articles for information. They also were the most likely to use print indexes, whereas White students were the least likely to use them. The use of ALADIN showed a reversed pattern.
These findings are somewhat troubling because they suggest that African American students have not taken full advantage of information technology. Because most of the White students are enrolling in $\mathrm{AU}$ and the African American students in UDC, it could be that AU's strong library support contributes to its students' heavy use of ALADIN. Or, it could be that other factors such as time or family may have kept some students from using ALADIN. Test statistics suggest race to be a factor, but further studies are necessary to understand fully its effects on students' use of online catalogs.

The three groups showed no difference in their reliance on roommates or friends for ideas. Nor were they different in their views on the factors that affected their choice of information channel; all three groups ranked "convenience," "quality of data," and "ease of use" as the top three factors.

Table 9 shows that half of the twentytwo dependent variables on students' ALADIN experience related to the race factor. Available data show that 25 per- 


\begin{tabular}{|c|c|c|c|}
\hline \multicolumn{4}{|c|}{$\begin{array}{l}\text { TABLE } 10 \\
\text { Experience with Library Associated with Race }\end{array}$} \\
\hline Variable & Chi-square & Cramer's V & Probability \\
\hline $\begin{array}{l}\text { Knowing how to make } \\
\text { good use of library } \\
\text { resources }\end{array}$ & 9.839 & 0.238 & 0.007 \\
\hline $\begin{array}{l}\text { Understanding the } \\
\text { research process }\end{array}$ & 14.035 & 0.200 & 0.007 \\
\hline $\begin{array}{l}\text { Understanding } \\
\text { research process is } \\
\text { critical to my future } \\
\text { career }\end{array}$ & 8.785 & 0.232 & 0.012 \\
\hline $\begin{array}{l}\text { Lack of time in learning } \\
\text { more about research } \\
\text { process }\end{array}$ & 6.128 & 0.194 & 0.047 \\
\hline $\mathrm{p}<.05$ & & & \\
\hline
\end{tabular}

cent of White students, 53 percent of the Asian-Hispanic group, and 73 percent of African Americans consulted library staff. Clearly, all users need some kind of assistance to make good use of the online catalog, and the system is not as userfriendly as librarians had hoped. In their use of ALADIN, students also showed different patterns. White students were most likely to:

- use ALADIN every time they visited a library,

- access ALADIN remotely,

- use whatever they can think of at the time for keyword searches,

- examine retrieved records for keywords,

- use whatever they can think of at the time for subject heading search,

- use Boolean operators in their ALADIN searches,

- consider keyword searching easy,

- consider moving between screens easy,

- have little difficulty in expanding searches,

- consider reducing a search result easy.

But African American students were least likely to use ALADIN in these ways. Race, however, was not the sole contribu- tor to the different behavior in using ALADIN, because other factors such as economic background also are involved.

Table 10 shows that only four of the fourteen dependent variables on students' experience with their libraries related to the race factor. Data show that fewer students of the Asian-Hispanic group thought they knew how to make good use of library resources and that more students of this group reported little understanding of the research process than the other two groups.

The three groups differed little in their views on research. They agreed that research is critical to their future career, but more African American students and students of the Asian-Hispanic group said they did not have time to learn about research. The three groups thought everyone should know about research, expressed a desire to conduct their own research, and shared an understanding that knowing how to do research is important for advanced studies.

\section{School As a Factor}

Table 11 shows that fifteen of the fortyfour dependent variables related to the school variable. Perhaps because most White students were from AU and most 


\begin{tabular}{|c|c|c|c|}
\hline \multicolumn{4}{|c|}{$\begin{array}{c}\text { TABLE } 11 \\
\text { Dependent Variables Associated with School }\end{array}$} \\
\hline \multirow[t]{2}{*}{ Variable } & Chi-square & Phi or $\mathrm{V}^{\mathrm{a}}$ & Probability \\
\hline & \multicolumn{3}{|c|}{ Use of Information Channels } \\
\hline References & 8.65 & 0.218 & 0.003 \\
\hline Print indexes & 24.226 & 0.365 & 0.000 \\
\hline \multirow[t]{2}{*}{ ALADIN } & 11.646 & 0.253 & 0.001 \\
\hline & \multicolumn{3}{|c|}{ Experience with ALADIN } \\
\hline $\begin{array}{l}\text { Learning ALADIN from } \\
\text { library staff }\end{array}$ & 17.548 & 0.326 & 0.000 \\
\hline Frequency of library use & 9.426 & 0.243 & 0.009 \\
\hline Remote access to ALADIN & 22.79 & 0.372 & 0.000 \\
\hline $\begin{array}{l}\text { Using whatever I can think } \\
\text { of for keyword searches }\end{array}$ & 13.351 & 0.285 & 0.000 \\
\hline $\begin{array}{l}\text { Using whatever I can think } \\
\text { of for subject heading }\end{array}$ & 14.802 & 0.3 & 0.000 \\
\hline Using LCSH & 5.116 & 0.177 & 0.024 \\
\hline Using Boolean operators & 9.25 & 0.244 & 0.002 \\
\hline Keyword search is easy & 9.38 & $0.242(\mathrm{~V})$ & 0.025 \\
\hline Moving between screens is easy & 9.761 & $0.247(\mathrm{~V})$ & 0.021 \\
\hline \multirow[t]{2}{*}{ Expanding a search is hard } & 10.498 & $0.257(\mathrm{~V})$ & 0.015 \\
\hline & \multicolumn{3}{|c|}{ Experience with Libraries } \\
\hline $\begin{array}{l}\text { Understanding research } \\
\text { process }\end{array}$ & 11.939 & $0.261(\mathrm{~V})$ & 0.003 \\
\hline $\begin{array}{l}\text { Interest in learning } \\
\text { more about research }\end{array}$ & 5.564 & $0.185(\mathrm{P})$ & 0.018 \\
\hline \multicolumn{4}{|c|}{$\begin{array}{l}\text { aphi and Cramer's V measure the strength of the relationship between two variables. Phi is } \\
\text { calculated for two-by-two tables, and V is calculated for tables larger than two-by-two. The value } \\
\text { for V is marked by (V). } \\
p<.05\end{array}$} \\
\hline
\end{tabular}

African American students were from UDC, some findings on the school variable are similar to those on the race variable. Of the five most popular information channels, test statistics show that UDC students were more likely to use references and print indexes and AU students were more likely to use ALADIN.

Regarding the use of ALADIN, students displayed the patterns reported under the race variable. The two groups also differed in how they viewed the research process. Data suggest that AU students had more confidence in their understanding of the research process and
UDC students were more interested in learning more about research.

\section{Economic Background As a Factor}

The author coded respondents into three categories to analyze the economic background factor: from families with an income of less than $\$ 30,000$, those with an income of more than $\$ 30,000$, and those with no income information. As table 12 illustrates, the three groups showed no difference in their use of information channels or their assessment of the factors that affected their selection of information channels. They showed more dif- 


\begin{tabular}{|lccc|}
\hline \multicolumn{4}{|c|}{$\begin{array}{c}\text { TABLE 12 } \\
\text { Dependent Variables Associated } \\
\text { with Economic Background }\end{array}$} \\
\hline \hline & Chi-square & Cramer's V & Probability \\
\hline Variable & 7.969 & 0.22 & 0.019 \\
\hline $\begin{array}{l}\text { Learning from on-screen } \\
\text { instructions }\end{array}$ & 13.927 & 0.209 & 0.008 \\
$\begin{array}{l}\text { Frequency of ALADIN use } \\
\text { Remote access to ALADIN }\end{array}$ & 6.535 & 0.20 & 0.038 \\
$\begin{array}{l}\text { Using retrieved records } \\
\quad \text { for keywords }\end{array}$ & 8.002 & 0.222 & 0.018 \\
$\begin{array}{l}\text { Using LCSH } \\
\text { Using truncation }\end{array}$ & 9.204 & 0.238 & 0.01 \\
$\begin{array}{l}\text { Reducing a search is easy } \\
\text { Understanding of } \\
\text { research process }\end{array}$ & 22.046 & 0.22 & 0.03 \\
Doing one's own research & 10.195 & 0.171 & 0.001 \\
\hline p<.05 & 10.734 & 0.257 & 0.037 \\
\hline
\end{tabular}

ferences in their experience with ALADIN and their experience with libraries. Test statistics suggest that the most affluent group was most likely to use ALADIN every time it visited a library, the less affluent group was more likely to use ALADIN sometimes, and the no-response group used ALADIN only when an assignment needed to be done. Except for access from campus computers, remote access requires some financial commitment, and it is therefore not surprising that the groups differed in this activity. As for their views of research, the no-response group contributed most to the differences by having more members reporting "little understanding" and showing no interest in doing their own research.

\section{Summary of Findings on Gender, Part-Time Job, and Children}

Nearly 60 percent of the respondents were female. Test results show that they were more likely to consult parents than male students were and that, in searching ALADIN, male students were more likely to use Boolean operators. Sixty-seven percent of the respondents reported having a part-time job. Test results indicate that these students were more likely to use
ALADIN every time they visited a library and to use the library only when a paper was due. They had less success, however, in searching ALADIN than others. Only 18 percent of the respondents had one to five children, and these respondents were more likely to use print indexes and seek help from library staff in learning ALADIN than those without children.

\section{Variables Affected by Multiple Independent Variables}

Seventeen dependent variables related to more than one independent variable. As table 13 shows, race was an important factor that related to most of the seventeen dependent variables. It also appeared often with school or economic background to contribute to students' use of information channels, experience with ALADIN, and experience with libraries.

\section{Implications \\ Validation of Established Information Channels}

At least 70 percent of the students used online catalogs, book and article references, and librarians, affirming the importance of these channels. Because students favored channels that were easy for 
TABLE 13

Dependent Variables Associated with Multiple Factors

Dependent Variable

Variable on Information Channels

Parents

References

Print indexes

Online catalogs

Variable on Use of ALADIN

Learning ALADIN from library staff

Frequency of ALADIN use

Remote access to ALADIN

Using whatever I can think of for keywords

Using retrieved records for keywords

Using LCSH

Using whatever I can think of for subject headings

Using Boolean operators

Keyword search is easy

Moving between screens is easy

Expanding a search is difficult

Reducing a search is easy

Variable on Views of Research

Understanding of research process

them to get to and that contain good information, academic libraries should continue to invest in online catalogs by augmenting their contents with high-quality data. Research and academic institutions also should invest in librarians who have effectively bridged users to information sources. Librarians' work is much appreciated by college students, and with the incorporation of information technologies into higher education, their roles will probably become more important.

\section{Improvements to Augmented Catalog, Such As ALADIN}

Because many students preferred exploring ALADIN by themselves, librarians should design online instruction that facilitates self-teaching. The default screen display should include subject headings so that more users will be able to take advantage of the subject analysis librar-
Factor

Race, Gender, Children

Race, School

Race, School, Children

Race, School

Race, School, Children

Race, School, Economic

Background, Part-Time Job

Race, School, Economic Background

Race, School

Race, Economic Background, Gender

Race, Economic Background

Race, School

School, Gender

Race, School

Race, School

Race, School

Race, Economic Background

Race, School, Economic Background

ians provide. In addition, librarians need to develop instruction sheets or an online demonstration module that will illustrate the differences between keyword searches and subject heading searches, and will enable users to decide when a particular type of search will be most effective. To make search expansion and reduction easier, more context-specific help messages should be provided. As for classification number searches, because most users consider call numbers the addresses of items in their collection and few consider them access points, librarians can help them appreciate the retrieval power of classification numbers through instruction workshops or online instruction.

\section{Enhanced Library Services and Instruc- tion on Research}

Data indicate that students use libraries for serious purposes. Most of them knew 
how to make good use of library resources and indicated that collection failure was the main reason for search failure. Librarians can address this issue by improving document delivery and stack management. Because most students appreciate the importance of research and want to conduct their own, librarians can develop courses on information management to introduce students to the research process, the variety of relevant information tools, and the skills to synthesize information from various sources.

\section{Use of Information Technology and Race}

Librarians realize that technology could widen the gap between information haves and information have-nots, and, therefore, advocate equal access for all users. Because this study found that more affluent students tend to use ALADIN more often, less affluent students would certainly benefit from librarians' advocacy for equal access. But the study also found that equal access does not lead to equal use. Despite the same access to the same information system, White students used ALADIN the most and African American students the least. Test results indicate that many factors contributed to the low use of ALADIN, and there are probably many more factors related to this phenomenon. The study identified factors related to students' use of information channels. The exact contribution of various factors and their interaction await further investigation.

\section{Conclusion}

Although the study focused on two universities in a particular city, several findings are consistent with earlier studies and confirm librarians' opinions and views about student users. In addition, the study sheds light on the range of information channels college students use, their selection criteria, their use of an online catalog, their self-assessment of library knowledge and research, and the relationships between six factors and their use of information channels. The researchers hope that these findings will encourage library administrators to develop programs and services that will facilitate undergraduate students' informationseeking, provide system designers and managers with ideas for improving information systems, and prompt administrators of higher education to address the special needs of various user groups.

Note: This study was supported by a Cooperative Grant for Faculty from the Consortium of Universities of the Washington Metropolitan Area. The project was conducted with the assistance of Albertine C. Johnson, Chairperson of the Public Services Department at the University of the District of Columbia, and Elizabeth B. Nibley, Reference Librarian at the American University.

\section{Notes}

1. See, for example, Larry Hardesty, Student Use of the Libraries at DePauw University, 1980, ERIC, ED 187335; and Tony Mays, "Do Undergraduates Need Their Libraries?" Australian Academic and Research Libraries 17 (June 1986): 51-62.

2. Judith Andrews, "An Exploration of Students' Library Use Problems," Library Review 40 (1991): 5-14.

3. Constance Mellon, "Library Anxiety: A Grounded Theory and Its Development," College $\mathcal{E}$ Research Libraries 47 (Mar. 1991): 160-65.

4. Nigel Ford, "Psychological Determinants of Information Needs: A Small-Scale Study of Higher Education Students," Journal of Librarianship 18 (Jan. 1986): 47-62.

5. Kathleen Dunn, "Psychological Needs and Source Linkages in Undergraduate Information-Seeking Behavior," College \& Research Libraries 47 (Sept. 1986): 475-81.

6. Mays, "Do Undergraduates Need Their Libraries?" passim.

7. Ford, "Psychological Determinants," passim.

8. Mays, "Do Undergraduates Need Their Libraries?" passim. 
9. Stephen A. Osiobe, "Information Seeking Behavior," International Library Review 20 (July 1988): $337-46$.

10. Barbara Fister, "The Research Processes of Undergraduate Students," Journal of Academic Librarianship 18 (July 1992): 163-69.

11. See, for example, Kenneth Dowlin, "Online Catalog User Acceptance Survey," RQ 20 (fall 1980): 44-47; Carole Weiss Moore, "User Reactions to Online Catalogs: An Exploratory Study," College \& Research Libraries 42 (July 1981): 295-302; Joseph R. Matthews, Gary S. Lawrence, Douglas K. Ferguson, eds., Using Online Catalogs: A Nationwide Survey (New York: Neal-Schuman, 1983); and David Steinberg and Paul Metz, "User Response to and Knowledge about an Online Catalog," College \& Research Libraries 46 (Jan. 1984): 66-70.

12. See, for example, Sue Pease and Mary Noel Gouke, "Patterns of Use in an Online Catalog and a Card Catalog," College \& Research Libraries 43 (July 1982): 279-91; Carolyn O. Frost, Student and Faculty Subject Searching in a University Online Public Catalog, 1985, ERIC, ED 264872; Micheline Hancock, "Subject Searching Behavior at the Library Catalogue and at the Shelves: Implications for Online Interactive Catalogues," Journal of Documentation 43 (Dec. 1987): 303-21.

13. See, for example, Karen Markey, "Thus Spake the OPAC User," Information Technology and Libraries 2 (Dec. 1983): 381-87; David W. Lewis, "Research on the Use of Online Catalogs and Its Implications for Library Practice," Journal of Academic Librarianship 13 (July 1987): 152-57.

14. See, for example, Sammy R. Alzofon and Noelle Van Pulis, "Patterns of Searching and Success Rates in an Online Public Access Catalog," College \& Research Libraries 45 (May 1984):11015; Matthews, Lawrence, and Ferguson, Using Online Catalogs; and Steinberg and Metz, "User Response."

15. Pat Ensor, "User Characteristics of Keyword Searching in an OPAC," College \& Research Libraries 53 (Jan. 1992): 72-80.

16. Karen Markey, Online Catalog Use: Results of Surveys and Focus Group Interviews in Several Libraries (Dublin, Ohio: OCLC, 1983).

17. Pat Ensor, Keyword/Boolean Searching on an Online Public Access Catalog: Patrons and Their Perceptions, 1990, ERIC, ED 337163.

18. Karen Markey and Anh N. Demeyer, Dewey Decimal Classification Online Project: Evaluation of a Library Schedule and Index Integrated into the Subject Searching Capabilities of an Online Catalog (Dublin, Ohio: OCLC, 1986).

19. Jeffrey C. Heustis, "Clustering LC Classification Numbers in an Online Catalog for Improved Browsability," Information Technology and Libraries 7 (Dec. 1988): 381-93.

20. Marcia J. Bates, "Rethinking Subject Cataloging in the Online Environment," Library Resources \& Technical Services 33 (Oct. 1989): 400-12.

21. Mary Micco and Rich Popp, "Improving Library Subject Access (ILSA): A Theory of Clustering Based in Classification," Library Hi Tech 12 (1994): 55-66.

22. Diane Vizine-Goetz and Karen Markey Drabenstott, "Computer and Manual Analysis of Subject Terms Entered by Online Catalog Users," in Proceedings of the 54th ASIS Annual Meeting (Medford, N.J.: Learned Information, 1991), 156-61.

23. Ray R. Larson, "Classification Clustering, Probabilistic Information Retrieval, and the Online Catalog, " Library Quarterly 61 (Apr. 1991): 133-73.

24. Evelyn Margaret Kirensen, "Studying Dial-Up Use at UC Berkeley," DLA Bulletin 7 (Dec. 1987): $12-14$.

25. Pamela Snelson, "Remote Users of OPACs: Do They Differ from Library Users?" in Proceedings of the 1994 Conference on Integrated Online Library Systems (Medford, N.J.: Learned Information, 1994), 179-83.

26. INNOPAC and NLS, an in-house system developed for the University of Wisconsin-Madison, both provide searchers the capability to retrieve more items directly from subject headings displayed on the screen. For subject searches, INNOPAC also displays authorized subject headings and cross-references. 


\title{
Association of College and Research Librapies
}

\section{Why did nearly 11,000 academic librarians and staff join ACRL?}

\author{
World-class publications
}

Standards, Guidelines

Advisory services

Leadership roles

Networking

Discounts

Sections

Advocacy

Newsletters

Local chapters

Career resources

Awards, Fellowships

Professional development

Electronic communications

\section{Find out what ACRL can do for you!}

Call: $1-800-545-2433$, ext. 2521 or 2510

E-mail: ctaylor@ala.org or nhale@ala.org 